\title{
Su İdarelerinin Su Kayıp Yönetim Performansının Analizi ve Temel Performans Gösterge Hesaplama Aracının Geliştirilmesi
}

\author{
Mahmut Fırat ${ }^{1, \oplus}$, Cansu Orhan² ${ }^{2}$, Salih Yılmaz ${ }^{3} \oplus$, Özgür Özdemir ${ }^{4} \oplus$ \\ ${ }^{1}$ Inönü Üniversitesi İnşaat Mühendisliği Bölümü, 44210, Malatya. \\ ${ }^{2}$ Ardahan Üniversitesi, Ardahan Teknik Bilimleri Meslek Yüksekokulu, 75002, Merkez, Ardahan. \\ ${ }^{3}$ Malatya Su ve Kanalizasyon Idaresi Genel Müdürlüğü, Yeşilyurt, Malatya. \\ ${ }^{4}$ Kayseri Büyükşehir Belediyesi Su ve Kanalizasyon İdaresi Genel Müdürlügü, 38090, Kocasinan, Kayseri.
}

\section{Özet}

$\mathrm{Su}$ kayıp yönetiminde, sistem davranışının izlenmesi ve sistem performansının uygun göstergelere göre analiz edilmesi işletme koşullarının iyileştirilmesi açısından oldukça önemlidir. Ancak bu analizlerin doğru, düzenli, sistematik ve hassas bir șekilde yapılması için uygun hesaplama araçlarının kullanılması gerekir. Bu nedenle, bu çalışmada kentsel su kayı yönetiminde su kayıpları ile mücadelede süreç performansının analiz edilmesi ve izlenmesi amactyla literatür esas alınarak en uygun göstergeler belirlenmiştir. Bu göstergelerin belirlenmesinde Uluslararası Su Birliği (IWA) ve diğer kuruluşlar tarafindan önerilen göstergeler detaylı bir şekilde analiz edilmiş ve su kayıp yönetimi açısından en uygun göstergelerin seçilmiştir. Belirlenen bu performans göstergelerinin sistematik bir șekilde hesaplanmast ve performansin izlenmesi için web tabanl "GGS temel performans analizi hesaplama aracı" geliștirilmiștir. $B u$ hesaplama aracı temel olarak, hacimsel ve yüzdesel göstergeleri, servis bağlantı ve hat uzunluğu başına göstergeleri, idari ve fiziki kayıp, ekonomik ve maliyet, arıza ve şebeke rehabilitasyon göstergelerini içermektedir. Bu hesaplama aracının detayları paylaşılmış, sağladığı avantajlar tartışılmış ve örnek veriler için analiz yapılmıştır. Geliştirilen bu hesaplama aracının, İdarelerin su kayıp yönetimi ve bileşenleri açısından performansının analiz edilmesi, izlenmesi ve aktif kaçak kontrolü faaliyetleri için süreç performansının değerlendirilmesinde önemli katkılar sağlayacă̆ı düşünülmektedir.

$\underline{\text { Anahtar Sözcükler }}$

Su Kayıp Yönetimi, Gelir Getirmeyen Su, Performans Değerlendirme, Performans Göstergeleri

\section{Analysis of Water Loss Management Performance of Water Utilities and Development of Basic Performance Indicator Analysis Tool}

\begin{abstract}
In water loss management, monitoring system behavior and analyzing system performance according to appropriate indicators is very important for improving operating conditions. However, appropriate calculation tools should be used to make these analyzes accurately, regularly, systematically and precisely. Therefore, in this study, the most appropriate indicators were determined based on the indicators proposed IWA and other organizations in literature in order to analyze and monitor the process performance in water loss management. A web-based "GGS basic performance analysis calculation tool" has been developed to systematically calculate these indicators and monitor performance. This tool basically includes volumetric and percentage indicators, service connection and per line length indicators, administrative and physical loss, economic and cost, failure and network rehabilitation indicators. The details of this tool were detailed, its advantages were discussed by analyzing of sample data set. It is believed that this analysis tool developed in this study will provide significant contributions to the analysis and monitoring of the performance of the Utilities in terms of water loss management and its components, and to evaluate the process performance for active leakage control activities.
\end{abstract}

$\underline{\text { Keywords }}$

Water Loss Management, Non-Revenue Water, Performance Evaluation, Performance Indicators

\section{Giriş}

Kentsel su yönetiminde, teknik, ekonomik, işletme, yönetim ve abone memnuniyeti kapsamında sistem performansının analiz edilmesi, süreç performansının izlenmesi ve kıyaslanması için performans değerlendirme faaliyetleri gerçekleştirilmektedir. Performans analizinin yapılması, sistem için önemli olan bileşenlerin düzenli izlenmesi, zayıf yönlerin belirlenmesi ve iyileştirilmesi için en uygun yöntemin belirlenmesi, sistem işletme maliyetinin düşürülmesi ve abone memnuniyetinin arttırılması açısından oldukça önemlidir. Ancak bu değerlendirmelerin ve analizlerin yapılabilmesi için sistem performansının en uygun, uygulanabilir, kıyaslanabilir, anlaş1lır ve verisi ölçülebilir göstergelerle izlenmesi gerekir (Lambert vd. 1999; Hamilton vd. 2006; Liemberger vd. 2007; van den Berg ve Danilenko 2010; Alegre vd. 2012; 2016). 
Liemberger vd. (2007) gelir getirmeyen su ve bileşenlerinin sistem giriş hacminin yüzdesi alınarak elde edilmesiyle yapılan yanlışlıklar irdelenmiş ve görünür kayıp analizi için etkin operasyonel performans indisleri ihtiyacı vurgulanmıştır. Alegre vd. (2006) su temini sistemleri için performans göstergelerinin seçiminde ve tanımlanmasında sistemin amaç ve kısıtlarının belirlenmesi gerektiğini vurgulamıştır. Bir performans göstergesinin seçiminde göz önünde bulundurulması gereken ilkeler şu şekilde ifade edilmiştir; açık ve net bir biçimde tanımlanmalı, ilgili değişkenler göz önüne alındığında makul bir biçimde ulaşılabilir olmalı, denetlenebilir olmalı, idarenin özel koşullarından bağımsız ve evrensel olmalı, basit ve anlaşılması kolay olmalı, herhangi bir kişisel veya sübjektif değerlendirmeden uzak olmalıdır. Mutikanga vd. (2010), gelişmekte olan Ülkelerde su dağıtım sistemlerinin performansının değerlendirilmesinde, literatürde önerilen performans değerlendirme sistemlerinin uygulanabilirliğinin oldukça zor olduğunu belirtmiştir. Çalışma sonunda, gelişmekte olan ülkelerde performans değerlendirme için mevcut göstergeler arasından uygun olanlarının belirlenmesi gerektiği vurgulanmıştır. Shinde vd. (2013), önerilen performans göstergelerinin Japonya'da küçük ölçekli su ve kanal idarelerinde kullanılabilecek göstergelerin belirlenmesini amaçlamıştır. Literatürde başka kuruluşlar tarafından önerilen mevcut performans göstergelerinin oldukça karmaşı yapıya sahip olduğu, teknik ve ekonomik alt yapısı yeterli büyük su dağıtım için uygun olduğu ancak teknik, personel ve ekonomik durumdan imkanları kısıtlı su dağıtım sistemleri için uygulanabilir olmadığı vurgulanmıştır. Haider (2015) Kanada'da küçük ve orta ölçekli su idaresi için beş modülden oluşan çok seviyeli bir performans yönetimi çerçevesi geliştirmiştir. Çalışmada su idaresi için uygun performans göstergeleri tanımlanıp seçilmekte ve bunları mümkün olduğunca en az sayıda veri kullanarak performans kıyaslaması için kullanılmaktadır. Bu çalışma ile geliştirilen model, ekonomi, kaynak yetersizliği ve veri kısıtlamaları sebebiyle kıyaslama yapılamayan su kanal idareleri için oldukça kullanışlıdır. Chimene (2013), su kayıplarının yönetimi için mevcut sistemin durumu göz önüne alınarak bir strateji planı geliştirmek ve bu plan sayesinde gelecekte ne gibi faydalar elde edilebileceğini tahmin etmek, strateji planı için hedefleri tanımlamak ve bu hedeflere nasıl ulaşılacağını belirlemek amacıyla bir dizi olasılıklar incelenmiştir. Sharma (2008) su dağıtım şebekelerinde kayıpları anlama ve yönetmenin temel olarak iki adımdan oluştuğunu ifade etmiştir; i) şebeke özelliklerinin belirlenmesi ve saha uygulamalarının analizi, ii) uygun stratejiler için uygun çözüm araçlarının önerilmesi. Ayrıca, hassas su kaybı azaltma programının geliştirilmesi için farklı bileşenlerin göreceli ağırlıklarının iyi anlaşılmasının önemi vurgulanmıştır (Kanakoudis vd. 2014). Su idarelerinde, gelir getirmeyen su oranını azaltmada uygulanan yöntemlere karar vermeye yardımcı olmak için kullanıcı dostu bir karar destek sistemi geliştirmişlerdir. Karar destek sistemi, su şebekesi performans seviyesini değerlendirmekte ve öncelikli azaltma önlemlerinin listesini önermektedir. Creaco vd. (2018) aktif kaçak kontrolü ve basınç yönetimi faaliyetlerinin ekonomik performansını analiz etmiş ve sızıntı ve arıza oranları üzerindeki etkileri kapsamında değerlendirme yapmıştır. Sistem verimliliğinin sağlanması için, sızıntı ve arıza yönetimi için uygun göstergelerin kullanılması gerektiği, ekonomik göstergeler esas alınarak fayda maliyet analizinin yapılmasının uygun olacağını vurgulamıştır. Demirci vd. (2018) pilot bölgelerde sistem performansının finansal ve üretim parametreleri kapsamında değerlendirilmesini ve analiz edilmesini amaçlamış ve bunun için veri zarfı yöntemini uygulamıştır. Ganjidoost vd. (2018) su ve atıksu yönetimi kapsamında sistem performansının değerlendirilmesi ve kıyaslanması amacıyla sosyo-politik, finansal ve alt yapı ana bileşenleri dikkate almıştır. Çalışmada, performans değerlendirme ve kıyaslama ile sistemin uzun dönemli su yönetiminin oluşturulması ve sistem davranışının tahmin edilmesi kapsamında kullanılabileceğini vurgulanmıştır.

Literatürden de görüldüğü gibi, sistem performansının değerlendirilmesi, teknik ve ekonomik açıdan sistemin izlenmesi için oldukça önemlidir. Ancak bu analizin en uygun göstergelere göre yapılması gerektiği ve su kayıplarının tanımlanmasında uygun göstergelerin kullanılması gerektiği ifade edilmektedir. Performans değerlendirme sisteminde gösterge sayısının çok olmasından ziyade göstergelerin; sistemi temsil eden, uygun, uygulanabilir, verisi toplanabilir ve en önemlisi referans bilgi üretebilir olması önemlidir. Bu nedenle, bu çalışmada kentsel su yönetiminde su kayıpları ile mücadelede süreç performansının analiz edilmesi ve izlenmesi amacıyla literatür esas alınarak en uygun göstergeler (10 ana başlık) belirlenmiştir. Bu göstergelerin belirlenmesinde Uluslararası Su Birliği (IWA), Amerikan Su İşleri Birliği (AWWA) ve diğer kuruluşlar tarafından önerilen göstergeler ve çalışmalar detaylı bir şekilde analiz edilmiş, su kayıplarının değerlendirilmesine, süreç içinde değişimlerin izlenmesine, sistemlerin birbiri ile kıyaslanmasına imkan tanıyan en uygun olanlar seçilmiştir. Ayrıca, bu göstergelerin hesaplanmasında kullanılan değişkenlerin verisinin düzenli bir şekilde ölçülebilir olması da göz önünde bulundurulmuştur. Belirlenen bu göstergelerin sistematik bir şekilde hesaplanması ve performansın izlenmesi için web tabanlı "GGS temel performans analizi hesaplama aracı" geliştirilmiştir. Bu hesaplama aracı ve alt modülleri temel hedef kitlesi Su ve Kanalizasyon İdareleri ve İl Belediyeleridir. $\mathrm{Bu}$ hesaplama aracının detayları paylaşılmış, sağladığı avantajlar tartışılmış ve örnek veriler için analiz yapıllmıştır. Literatür incelendiğinde su kayıp yönetimi açısından bu kadar kapsamlı ve sistematik analiz yapabilen, değerlendirme sunan, süreç performansının izlenmesine imkan tanıyan ve bütünleşik çalışan herhangi bir hesaplama aracına rastlanılmamıştır. Ülkemizde bu kapsamda İdareler referans oluşturacak bilgi üreten herhangi bir aracın olmadığı göz önüne alındığında, geliştirilen bu hesaplama aracının, İdarelerin su kayıp yönetimi ve bileşenleri açısından performansının analiz edilmesi, izlenmesi ve aktif kaçak kontrolü faaliyetleri için süreç performansının değerlendirilmesinde önemli katkılar sağlayacağı düşünülmektedir. 


\section{Su kayıpları}

İçme suyu dağıtım sistemlerinde çeşitli faktörlere bağlı olarak meydana gelen su kayıpları temel olarak İdari kayıplar ve Fiziki kayıplar olmak üzere iki şekilde sınıflandırılabilir (Lambert vd. 1999; Lambert 2002; Farley vd. 2008). Fiziki kayıplar, kaynaktan itibaren sistemin herhangi bir noktasında (iletim hattı, depo, dağı̆ım sistemi, servis bağlantısı) meydana gelmektedir. Diğer taraftan İdari kayıplar, sayaç hatalarından kaynaklanan kayıplar, kaçak kullanımlar ve muhasebe hataları gibi bileşenleri içermektedir (Lambert vd. 1999; Lambert 2002; Farley vd. 2008). Su kayıpları İdareler için ciddi ekonomik sonuçlar doğurmaktadır. Abonelere ulaştırılamadığı için satılamayan sular, arızalar nedeniyle oluşan bakım-onarım giderleri, su üretimi ve iletimi için gerekli enerji giderleri ile alternatif kaynak arayışları ciddi maliyetler meydana getirmektedir ve gelir getirmeyen su (GGS) hacminin önemli bir bölümünü oluşturmaktadır (Farley ve Trow 2003; Lambert ve Lalonde 2005; Pearson ve Trow 2005). Ayrıca sistemde, park-bahçe sulaması, ibadethane kullanımları ve yangın hidrantı kullanımı gibi yasal ancak ücreti alınamayan tüketimler de yer almaktadır. Bu tüketimler İdareler için gelir getirmeyen su (GGS) hacminin bir bileşeni olarak ifade edilir. GGS, sisteme verilen ancak ücreti alınamayan su olarak tanımlanır ve su kayıplarına ilave olarak yasal ancak faturalandırılmamış tüketimleri de içermektedir (Lambert vd. 1999; Lambert 2002; Farley vd. 2008). Kentsel su yönetiminde GGS oranının azaltılması ve gelir oranının arttırılması esas olmalıdır. Bunun için sistemdeki sızıntıların önlenmesi, kaçak kullanım ve sayaç hatalarından kaynaklanan kayıpların ve yasal ancak faturalandırılmamış tüketimlerin azaltılması gerekir. Bu nedenle sistemin düzenli olarak izlenmesi, sızıntıya sebep olan faktörlerin etkilerinin azaltılması, saha denetimleri ve testleri yaparak doğrudan gelir kaybına sebep olan bileşenlerin kontrol edilmesi ve en önemlisi uygulanan yöntemlerden elde edilen sonuçların temel performans göstergeleri ile analiz edilmesi ve izlenmesi gerekir.

\section{Su Kayıpları için Temel Performans Göstergeleri}

IWA (2001)'e göre “Performans Kıyaslama, sistematik arama/izleme ve önde gelen (en iyi) uygulamaların uyarlanması yoluyla performansın iyileştirilmesi için bir araçtır”. Bir dağıtım sisteminin performansının, açıkça tanımlanmış metodolojiye göre, standart tanımlar kullanarak hesaplanmış ve standart hale getirilmiş performans göstergelerine göre değerlendirilmesi oldukça önemlidir. Performans analizi için seçilen göstergelerin, karşılaştırılabilir ve anlaşılır olması, denetlenebilir, basit ve uygulanabilir olması, ihtiyaca cevap verebilmesi ve sistemin gerçek performansını ifade etmeye katkıda bulunması, verilerinin ölçülebilir olması ve teknik personel ve karar vericiler için referans oluşturacak bilgi üretebilir olması oldukça önemlidir (Alegre vd. 2006; 2012). Su kayıp yönetiminde temel performans göstergelerinin kullanılması ile beklenen faydalar (Lambert 2002; Alegre vd. 2006; Haider 2015); (i) belirlenen tarihler arasında geçen süreç içinde performans değişiminin izlenmesi, (ii) uygulanan yöntemin başarısının test edilmesi ve fayda maliyet analizinin yapılması, (iii) İdarenin temel bileșenler bazında (su, enerji, gelir, ekonomik durum, personel, ekip) en iyi performansa sahip olması ve verimliliğin arttırılması, (iv) karar vericiler için kurumun eksik ve güçlü yanlarının ortaya konulması, (v) Kurumun performansının iyileştirilmesine yönelik yatırım planlamalarının ve yasal düzenlemelerin yapılması, yapılan yatırımların ve alınan kararların etkilerinin izlenmesi ve stratejilerin geliştirilmesi şeklinde verilebilir. Literatürde "Su ve Atıksu Yönetimi”" kapsamında "performans göstergelerinin hesaplanmasını" esas alan ve farklı kuruluşlar tarafından, kendi özel koşullarını ve işletme gereksinimlerini ifade eden ve yansıtan farklı terminolojiler kullanılmıştır. Bu kapsamda, Uluslararası Su Birliği (IWA), Amerikan Su İşleri Birliği (AWWA), Su ve Atıksu İdareleri için Uluslararası Kıyaslama Ağı (IBNET), Su Servisi Düzenleme Otoritesi (OFWAT), Asya Gelişim Bankası (ADB) ve Türkiye Su Enstitüsü (SUEN) tarafından çok fazla sayıda göstergeyi içeren değerlendirme sistemleri önerilmiştir. Bu sistemlerde önerilen temel ana kategoriler, su kaynağı, ölçüm, personel, fiziksel, işletme, service kalitesi, ekonomik ve finansal, GGS, varlıklar ve süreç göstergeleri şeklindedir. Diğer taraftan su kayıp yönetiminde sistem performansının değerlendirilmesi ve izlenmesinde, su dengesi, işletme/arıza yönetimi, abone yönetimi, idari kayıp, fiziki kayıp, ekonomik ve finansal göstergeler kullanılmaktadır. Performans değerlendirme sisteminde gösterge sayısının çok olmasından ziyade göstergelerin; sistemi temsil eden, uygun, uygulanabilir, verisi toplanabilir ve en önemlisi referans bilgi üretebilir olması önemlidir. Bu nedenle, bu çalışma kapsamında kentsel su yönetiminde su kayıpları ile mücadelede süreç performansının analiz edilmesi ve izlenmesi amaciyla literatürde önerilen göstergeler incelenmiş ve toplamda 10 ana başlık belirlenmişsir. $\mathrm{Bu}$ göstergelerin belirlenmesinde IWA, AWWA ve diğer kuruluşlar tarafından önerilen göstergeler detaylı bir şekilde analiz edilmiş ve su kayıp yönetimi açısından en uygun olanlar seçilmiştir. Bir sonraki bölümde bu göstergelerin detayları, hesaplanması, sonuçların yorumlanması ve literatürde verilen sınır değerler tartışılmıştır. Ayrıca belirlenen bu göstergelerin sistematik bir şekilde hesaplanması ve performansın izlenmesi için web tabanlı "GGS temel performans analizi hesaplama aracı" geliştirilmiş, detayları paylaşılmış, sağladığı avantajlar tartışılmış ve örnek veri seti için analiz yapılmıştır. 


\section{GGS Performans Analizi Hesaplama Aracının Geliştirilmesi}

Bir dağıtım sisteminin performansının, açıkça tanımlanmış metodolojiye göre, standart tanımlar kullanarak hesaplanmış ve standart hale getirilmiş performans göstergelerine göre değerlendirilmesi oldukça önemlidir. Kentsel su yönetiminde $\mathrm{Su}$ İdarelerinde ve Belediyelerde çalışan teknik personel ve karar vericiler için sistemin çeşitli parametrelere göre performansının analiz edilmesi ve izlenmesi amacıyla "GGS temel performans analizi hesaplama aracı" geliştirilmiştir. $\mathrm{Bu}$ hesaplama aracı çeşitli araştırmacılar tarafından önerilen ve sistemde GGS ve alt bileşenlerini çeşitli parametrelere göre değerlendiren göstergeleri hesaplamaktadır. Bu hesaplama aracında yer alan gösterge ana başlıkları; (i) Hacimsel ve Sistem Net Giriş Hacmi (SIV) \% si olarak GGS performansı, (ii) Birim Servis Bağlantı sayısına göre Performans Göstergeleri, (iii) Birim ana hat uzunluğuna göre Performans Göstergeleri, (iv) Fiziki Kayıp Göstergeleri, (v) İdari Kayıp Göstergeleri, (vi) Ekonomik Göstergeler, (vii) Su Kaynağı ve Tüketimi Göstergeleri, (viii) Arıza Oranı Göstergeleri, (ix) Şebeke Rehabilitasyon Göstergeleri (x) GGS Maliyet Göstergeleri, şeklindedir. GGS temel performans analizi hesaplama aracı, sistemde ayrıca geliştirilen "su dengesi", "minimum gece debisi (MNF)" ve "alt yapı kaçak indeksi (ILI)" hesaplama araçları ile bütünleşik çalıştığ 1 gibi bağımsız bir şekilde de analiz yapabilmektedir. Modüllerin bütünleşik çalışması, GGS Performans analizinde gerekli olan ve su dengesi, MNF ve ILI modüllerinde tutulan veriler veya bu modüllere ait analiz sonuçları GGS Performans analiz sayfasına otomatik gelmekte ve tekrar veri girişine gerek kalmadan işleme katılmaktadır (Şekil 1). Ayrıca, sistemde şebeke ana hattı ve servis bağlantıları için ayrı ayrı olmak kaydıyla, rapor edilen ve edilmeyen arıza verileri, suyun üretim maliyeti, satış bedelleri, işletme maliyetleri, sistemin yıllık işletme gelir ve giderler gibi finansal verilerinin girilmesi gerekmektedir. Bu verilerin doğruluğu iyi bir arıza yönetim sistemine ve aktif kaçak kontrolünün uygulanmasına bağlıdır. Unutulmamalıdır ki, yapılan hesaplamaların DOĞRU sonuç vermesi, verilerin sahadan, DOĞRU ve SISTEMATİK olarak ölçülmesi ve en az tahmin verisinin kullanılması ile mümkündür. Literatürde su kayıplarının ve bileşenlerinin performansının izlenmesi için çeşitli göstergeler tercih edilmektedir. Performans analizi için en uygun göstergelerin seçilmesi ve bu göstergelerin sistematik ve doğru bir şekilde hesaplanması için uygun hesaplama araçlarının kullanılması oldukça önemlidir. Ancak bu göstergelerin bazılarının tek başına kullanılması anlamlı sonuç üretmeyebilir. Bu nedenle sistemi daha iyi temsil etmek ve değerlendirme yapmak için farklı göstergeleri aynı anda dikkate almak gerekir. Bu bölümde seçilen göstergeler, hesaplanması, detayları, sonuçların yorumlanması detaylandırılmıştır. Önceki bölümde verildiği gibi, geliştirilen GGS performans analiz hesaplama aracında veri girildikten sonra 10 ana başlıkta tanımlanan göstergeler otomatik hesaplanmakta, "gelişmiş veya gelişmekte olan ülke” seçimine göre literatürde önerilen sınır değerler ile otomatik olarak kıyaslama yapılmaktadır (Şekil 2).

\begin{tabular}{|c|c|c|c|c|}
\hline Form Tipi & Değişken Adı & Değer / (Yüzdelik) & Birim & Verinin Alınacağı Birim \\
\hline PI Analiz & Toplam Hizmet Edilen Nüfus Bilgi Al & ] kişi & O kişi & Abone ișleri D.B. \\
\hline PI Analiz & Hizmet Edilen Ticari Abone Sayısı & 5000 & Oadet & Abone ișleri D. B. \\
\hline PI Analiz & Hizmet Edilen Konut Abone Sayısı & 350000 & O adet & Abone ișleri $D . B$. \\
\hline PI Analiz & Toplam Abone SayIsI (otomatik hesaplanmakta) & 355000 & O adet & Abone ișleri D.B. \\
\hline PI Analiz & Bölgede Önemli Abonelerin Sayııı & adet & Oadet & Abone ișleri D.B. \\
\hline PI Analiz & Şebeke Anahat Uzunluğu (Lm) & 2000 & $0 \mathrm{~km}$ & İçmesuyu D.B. \\
\hline PI Analiz & Servis Bağlantlarırıın Toplam Uzunluğu (Lp) & 500 & $O \mathrm{~km}$ & iççmesuyu D.B. \\
\hline PI Analiz & Toplam Servis Bağlantı Sayııı ( $\mathrm{Nc}$ ) & 80000 & Oadet & iççmesuyu D.B. \\
\hline PI Analiz & Ortalama Servis Bağlantı Uzunluğu (Lpx) Bilgi Al & 6.25 & Om & iççmesuyu D.B. \\
\hline PI Analiz & Şebeke Ortalama Yaşı & 20 & Oyil & içmesuyu D.B. \\
\hline PI Analiz & Hizmet Alanı & 12000 & $\mathrm{Okm}$ & içmesuyu D.B. \\
\hline PI Analiz & Maksimum-Minimum kot farkı & 80 & $O \mathrm{~m}$ & iççmesuyu D.B. \\
\hline PI Analiz & Bilinen Vana Sayısı & 8000 & Oadet & İçmesuyu D.B. \\
\hline
\end{tabular}

a) Şebeke temel verileri 


\begin{tabular}{|c|c|c|c|c|c|}
\hline PI Analiz & İolasyon Vana Sayısı & 200 & adet & O adet & içmesuyu D.B. \\
\hline PI Analiz & Giriș Nokta Sayııı & 2 & |adet & ○ adet & içmesuyu D.B. \\
\hline PI Analiz & Çוkıs Nokta Sayııı & 1 & |adet & $\odot$ adet & Içmesuyu D.B. \\
\hline PI Analiz & Bağlantı Yoğunluğu (Nc / Lm) (Otomatik Hesaplanmakta) & 40.00 & sayl/km & O say $/ \mathrm{km}$ & iççmesuyu D.B. \\
\hline PI Analiz & Ortalama Sistem BasıncI $(P)$ & 50 & ]m & Om & içmesuyu D.B. \\
\hline PI Analiz & Sisteme Giriş Hacmi & 110000000 & ] 33 & m3 & içmesuyu D.B. \\
\hline PI Analiz & Diğer Sistemlere Iletilen Hacim(Çııış Hacmi) & 10000000 & m3 & ○ $\mathrm{m} 3$ & içmesuyu D.B. \\
\hline PI Analiz & Sistem Net Giriş Hacmi(SIV) & 100000000 & ] 33 & ○ m3 & içmesuyu D.B. \\
\hline PI Analiz & Faturalandırılmış Ölçülmüş Yasal Kullanım & 60000000 & m3 & $\mathrm{Om} 3 \mathrm{O}(\% \mathrm{SIV})$ & içmesuyu D.B. \\
\hline PI Analiz & Faturalandırılmış Ölçülmemiş Yasal Kullanım Bilgi Al & 1000000 & m3 & ○ $33 \mathrm{O}(\% \mathrm{sIV})$ & Abone işleri D.B. \\
\hline PI Analiz & Faturalandırılmamış Ölçülmüş Yasal Kullanım Bilgi Al & 1000000 & $\mathrm{~m} 3$ & $\mathrm{Om} 3 \mathrm{O}(\% \mathrm{siV})$ & Abone Ișleri D.B. \\
\hline PI Analiz & Faturalandırılmamış Ölçülmemiş Yasal Kullanım Bilgi Al & 1000000 & m3 & $\odot \mathrm{m} 3 \mathrm{O}(\% \mathrm{SIV})$ & Abone işleri D.B. \\
\hline PI Analiz & Yasadışı-Kaçak Kullanım Oranı Bilgi Al & 2000000 & m3 2 & $\mathrm{Om} 3 \odot(\% \mathrm{siV})$ & Abone ișleri D.B. \\
\hline PI Analiz & Abone Sayaç Hata Oranı Bilgi Al & 5 & $\%$ & ๑\% & Abone ișleri D.B. \\
\hline PI Analiz & Depolarda Meydana Gelen Kayıp Oranı(Fiziki Kayıp Hacminin \% si) Bilgi Al & 10 & $\%$ & $0 \%$ & İçmesuyu D.B. \\
\hline
\end{tabular}

b) Su bütçesi temel verileri

\begin{tabular}{|c|c|c|c|c|c|}
\hline PI Analiz & Bölgede Kaydedilen Yillık Șebeke Arrza Sayııı (Rapor Edilen) & 4000 & adet & O adet & Bilgi ișlem D.B. \\
\hline PI Analiz & Bölgede Kaydedilen Yillık Servis Bağlantı Arrza Sayııı (Rapor Edilen) & 6000 & |adet & O adet & Bilgi Ișlem D.B. \\
\hline PI Analiz & Bölgede Kaydedilen Yillık Şebeke Arıza Sayısı (Rapor Edilmeyen) & 400 & |adet & Oadet & Bilgi ișlem D.B. \\
\hline PI Analiz & Bölgede Kaydedilen Yillık Servis Bağlantı Ariza Sayııı (Rapor Edilmeyen) & 600 & |adet & ○ adet & Bilgi ișlem D.B. \\
\hline PI Analiz & Bölgede kaydedilen YIllik Toplam Rapor Edilen Ariza Sayııı (Hesaplanmakta) & 10000 & |adet & O adet & Bilgi işlem D.B. \\
\hline PI Analiz & Bölgede kaydedilen Yılllk Toplam Rapor Edilmeyen Arrza SayıII (Hesaplanmakta) & 1000 & |adet & O adet & Bilgi ișlem D.B. \\
\hline PI Analiz & Tahsilat Yapilan Toplam Hacim & 50000000 & m3 & Om3 & iç̧mesuyu D.B. \\
\hline PI Analiz & Fatura Döneminde Okunan Abone Sayısı & 284000 & adet $80 \quad \%$ Toplam abone sayısı & O adet $\odot \%$ Toplam abone sayııı & İçmesuyu D.B. \\
\hline PI Analiz & Suyun Üretim Maliyeti & 2 & TL/m3 & ○ TL/m3 & içmesuyu D.B. \\
\hline PI Analiz & Ișletme Geliri & 300000000 & TL & ○ TL & içmesuyu D.B. \\
\hline PI Analiz & işletme Maliyeti & 250000000 & TL & OTL & içmesuyu D.B. \\
\hline PI Analiz & Rehabilitasyonu Yapılan Hat Uzunluğu & 100 & km & Okm & içmesuyu D.B. \\
\hline PI Analiz & Değiștirilen Vana Sayısı & 500 & |adet & O adet & içmesuyu D.B. \\
\hline PI Analiz & Rehabilitasyon Yapılan Bağlantı Sayısı & 1000 & |adet & O adet & içmesuyu D.B. \\
\hline PI Analiz & Kaynaklardan Potansiyel Alinabilecek Su Hacmi & 1000000000 & m3 & Om3 & içmesuyu D.B. \\
\hline PI Analiz & Suyun Birim m3 için Satış Bedeli & 4 & TL/m3 & OTL/m3 & İçmesuyu D.B. \\
\hline
\end{tabular}

c) Arıza ve finansal temel verileri

Şekil 1: GGS performans analizi hesaplama modülleri veri giriş ekranı 


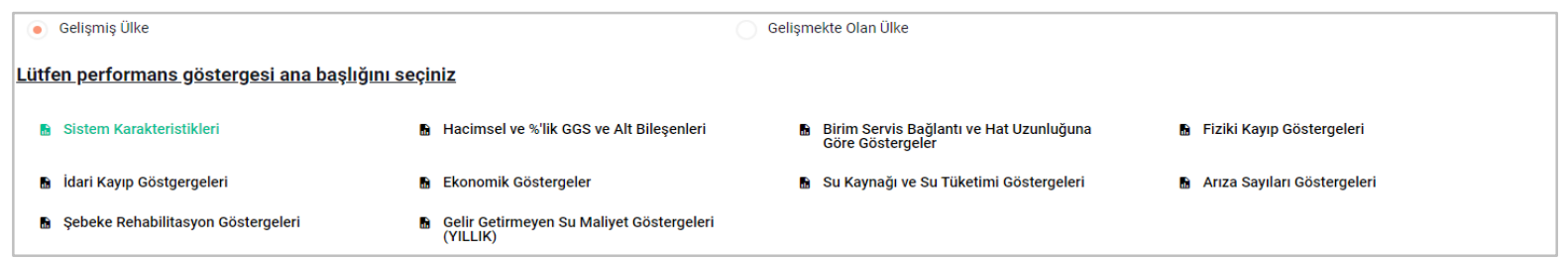

Şekil 2: GGS performans hesaplama aracı analiz sayfası

\subsection{Hacimsel ve Yüzdesel Olarak GGS Performans Analizi Modülü}

GGS ve alt bileşenlerinin performansının hesaplanması ve izlenmesi için hacimsel ve sistem giriş hacminin (SIV) \% 'si şeklinde ifade edilen göstergeler dikkate alınmış ve geliştirilen hesaplama aracına eklenmiştir. Bu kapsamda Şekil 1'deki veri giriş ekranında girilen değer esas alınarak, Hacimsel olarak 4 gösterge ve giriş hacminin \% si olarak ise 6 gösterge hesaplanmaktadır (Şekil 3). Ülkemizde Su İdarelerinin yıllık performansının izlenmesinde GGS oranı kullanılmaktadır. Literatür incelendiğinde hacimsel veya giriş hacminin \%'si şeklinde tanımlanan göstergelerin kullanılmasının uygun olmayacağı vurgulanmaktadır. Özellikle sistemin büyüklüğü, giriş hacminin ölçülmesi ve büyüklüğü, tüketilen suyun düzenli ölçülüp ölçülmemesi, abone davranışı, şebeke fiziksel durumu ve park-bahçe sulama yoğunluğu gibi faktörlerin GGS hacmi veya oranını etkilemektedir. Örneğin iki farklı Su İdaresi düşünürsek, sızıntı hacimleri aynı olmasına rağmen giriş hacimlerinin farklılığından dolayı GGS oranları farklı olmaktadır. GGS ve alt bileşenlerinin hacimsel hesaplanması özellikle, su kaynaklarının verimliliğinin ve ekonomik karşılığının hesaplanmasında kullanılmaktadır. Hesaplanan GGS oranı "değerlendirme sonucu" aracılığıyla literatürde önerilen sınır değerlerle kıyaslama imkanı sunulmaktadır.

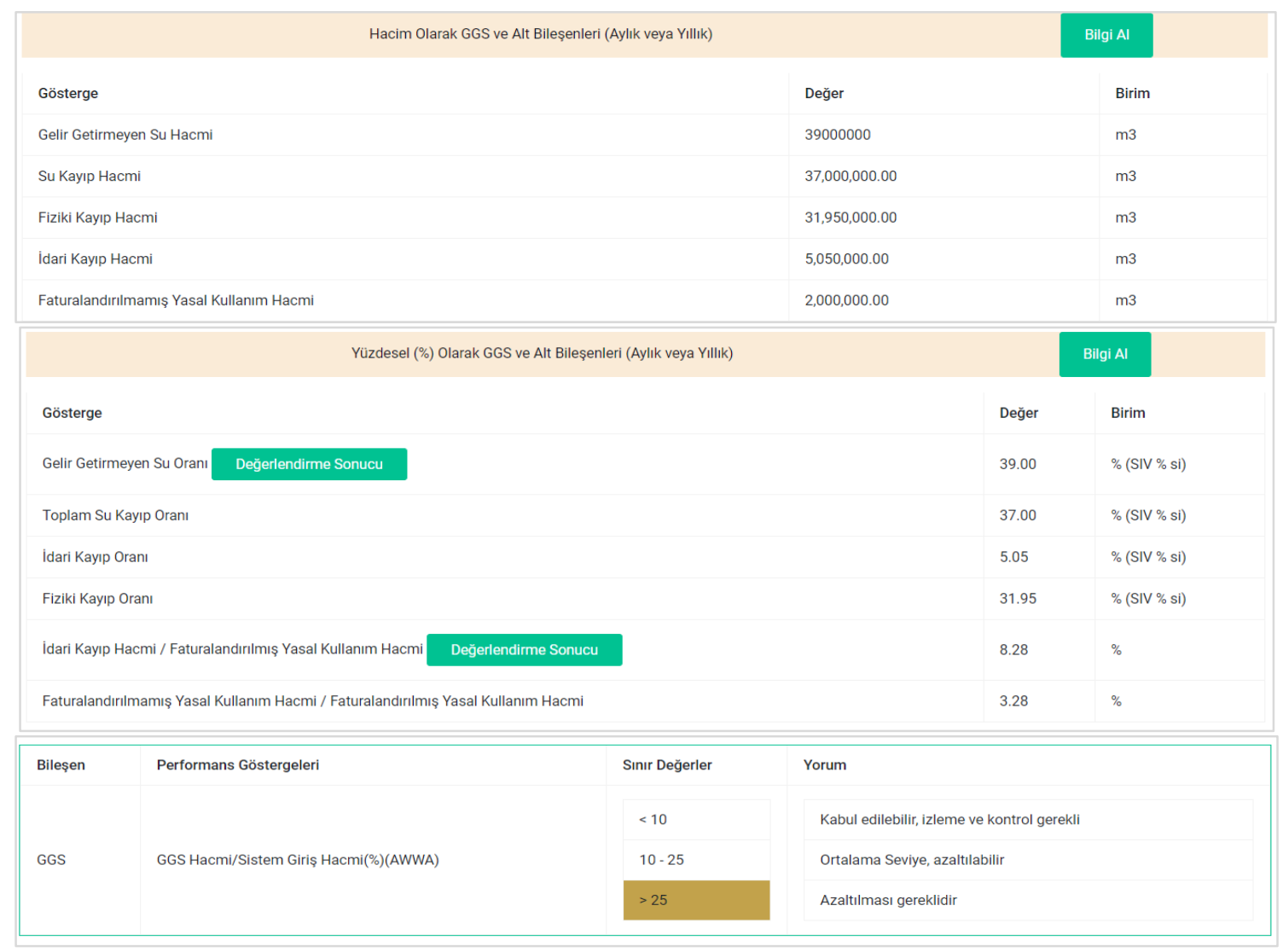

Şekil 3: Hacimsel ve \% olarak GGS performans analizi hesaplama modülü ara yüzü

Bu başlık altında verilen göstergeler, GGS ve alt bileşenlerinde hacimsel olarak meydana gelen kayıpları ifade etmekte ve özellikle mevcut durumda gerek su ve enerji kaynak verimliliğinin değerlendirilmesinde gerekse de bu bileşenlerin ekonomik etkilerinin analizinde referans oluşturmaktadır. Diğer taraftan, GGS ve alt bileşenlerinin yüzdesel değişimleri, Bakanlık tarafından her yıl Su İdarelerinden istenmekte ve sistem performansının izlenmesinde temel veri olarak kullanılmaktadır. Bu göstergelerin yıllık olarak düzenli hesaplanması, su kayıplarının önlenmesi için uygulanan yöntemlerden elde edilen kazanımların analizinde kullanılmaktadır. 
Ayrıca idari kayıp hacminin faturalandırılmış hacme oranını veren gösterge, İdarenin abonelere ilettiği ve ücretini alamadığı suyun parasal karşılığının değerlendirilmesinde veya bu oranı azaltarak ne kadar gelir elde edeceğinin değerlendirilmesine imkan tanımaktadır.

\subsection{Birim Servis Bağlantı ve Şebeke Uzunluğuna Göre Gösterge Modülü}

Su kayıp yönetiminde performans kıyaslama genelde, aktif kaçak kontrolü sürecinin kıyaslanması ve sistemlerin birbiri ile kıyaslanması olmak üzere iki amaç için yapılmaktadır. Süreç performansının kıyaslanmasında genelde şebeke fiziksel parametrelerini (servis bağlantı sayısı ve şebeke uzunluğu) dikkate alan göstergeler kullanılmaktadır. Bu göstergeler kullanılarak GGS ve alt bileșenlerinin sürecin başlangıcı ve sonunda değerleri hesaplanmakta ve süreç içinde performans değişimi izlenmektedir. Bu performans göstergeleri izole bölge bazlı yapılacağı gibi sistemin geneli için de kullanılmaktadır. Bu nedenle İdarelerde süreç performansının sistematik bir şekilde analizi için bu göstergeler hesaplama aracına tanımlanmıştır (Şekil 4).

Bu göstergelerin hesaplanmasında GGS ve alt bileşenlerinin kayıp hacimleri dikkate alındığı için süreç içerisinde aktif kaçak kontrolü yöntemlerinin (basınç yönetimi, MNF, İzole Ölçüm Bölgesi (DMA) vb.) etkileri izlenebilmektedir. Bu göstergelerin düşük değer alması, sistemin iyi bir performansa sahip olduğu göstermektedir. IWA ve Dünya Bankası tarafindan bu göstergeler için herhangi bir basınç seviyesi için oranları içeren tablolar önerilmiş ve bu tablolar ilgili göstergenin sonucunun kıyaslanması için "değerlendirme sonucu” butonuna tanımlanmıştır (Fiziki kayıp değerlendirme, Şekil 4). Böylece kullanıcılar sistemde veya süreç içinde göstergenin yer aldığı sınıfı belirleme ve kıyaslama imkanı bulacaktır.

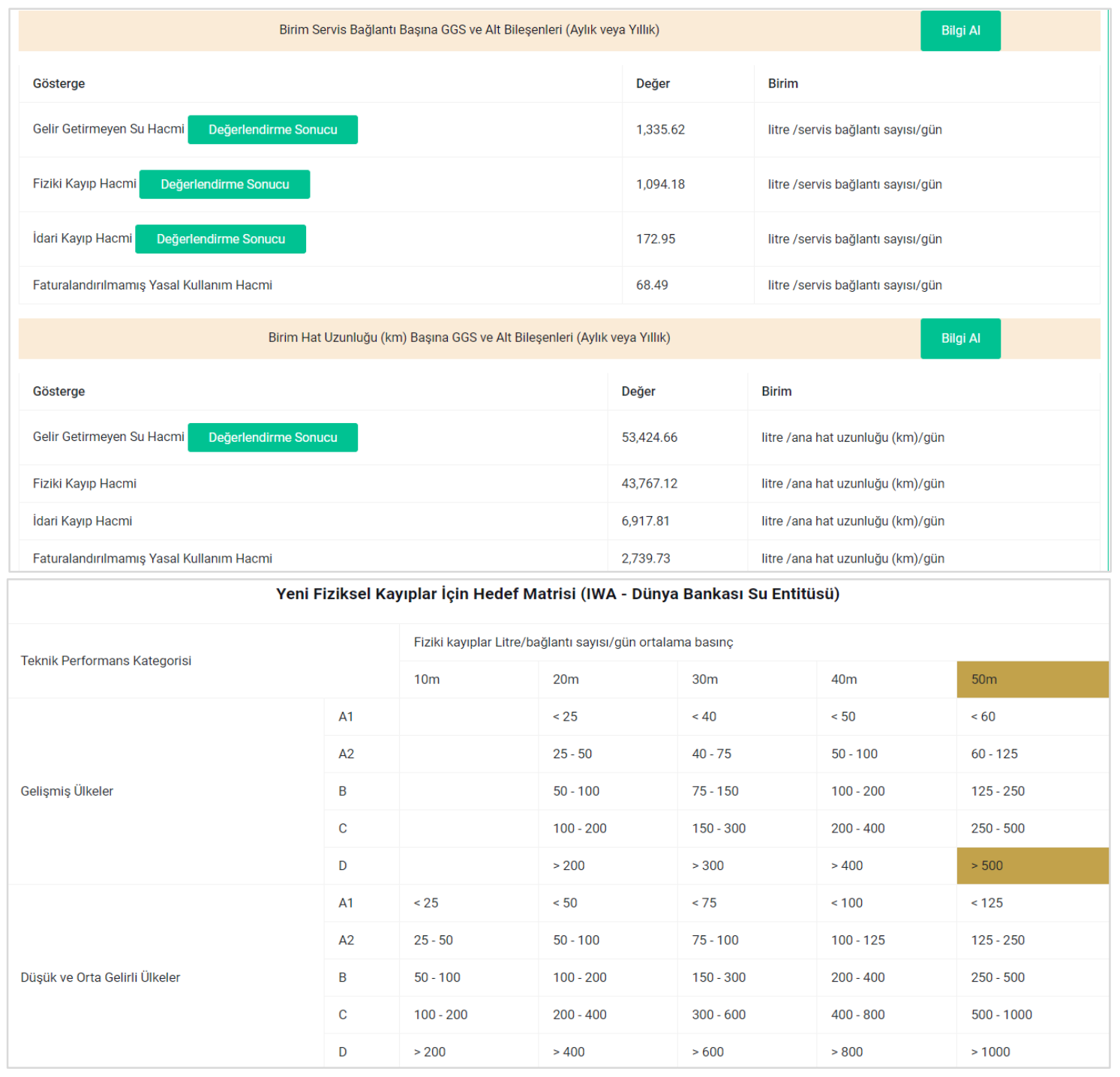

Şekil 4: Birim servis bağlantı ve şebeke uzunluğuna göre performans analizi hesaplama modülü 
Şekil 4'te verilen birim servis bağlantı başına veya şebeke uzunluğu başına verilen kayıp oranları özellikle aktif kaçak kontrolü yöntemlerinin uygulanmasına bağlı olarak sızıntı ve diğer kayıplardaki değişimlerin analizinde referans bilgi üretmektedir. Hesaplanan bu göstergeler, uluslararası literatürde önerilen sınır değerler ile kıyaslanarak sistemin performansının değerlendirilmesi mümkün olmaktadır. Örneğin yapılan hesaplamada $50 \mathrm{~m}$ basınç altında sistemde meydana gelen kayıplar 500 litre/servis bağlantı / gün/ ortalama basınç olarak hesaplanmış ve bu değerin literatürde önerilen tabloya göre oldukça yüksek seviyede olduğu görülmüştür. Bu sistemde aktif kaçak kontrolü uygulanarak bu değerin düşürülmesi için hedef tanımlanması ve zaman içinde bu hedefe ulaşıp ulaşılmadığının test edilmesi mümkün olmaktadır.

\subsection{Fiziki Kayıp Göstergeleri Modülü}

Bilindiği üzere, toplam su kayıplarının önemli bir kısmını fiziki kayıplar oluşturmakta ve bu kayıpların yönetilmesinde uygulanan yöntemler genelde maliyetli ve zaman alıcıdır. Bu kayıpların izlenmesi ve azaltılması özellikle su ve enerji verimliliği açısından oldukça önemlidir. Bu nedenle GGS performans analizi hesaplama aracında fiziki kayıplara ait temel göstergeler tanımlanmıştır. IWA tarafından önerilen ve sistemlerin kıyaslanmasında kullanılan tek gösterge ILI göstergesidir. Boyutsuz bir gösterge olan ILI göstergesinin hesaplanan değerine göre sistem sınıfı belirlenmekte, fiziki kayıpların değerlendirilmesi ve önleme yöntemlerinin performansının izlenmesine imkan sağlamaktadır. Ayrıca sistemin fiziksel özelliklerine göre teknik olarak en düşük sızıntı seviyesini gösteren Yıllık Kaçınılmaz Fiziki Kayıp Hacmi (UARL) hesaplanmaktadır. Son olarak birim basınç altında servis bağlantı başına veya şebeke uzunluğuna göre sızıntı göstergeleri de hesaplanmaktadır. Bu göstergeler özellikle sistem basıncına göre sızıntıdaki değişimi vermesi açısından kullanıcılar için önemli bilgi üretmektedir. Diğer modüllerde olduğu gibi bu modülde de göstergeler için önerilen sınır değerleri içeren tablolar hesaplama aracına eklenmiş ve kullanıcının sistemin mevcut durumunu kıyaslamasına imkan tanınmıştır (Şekil 5).

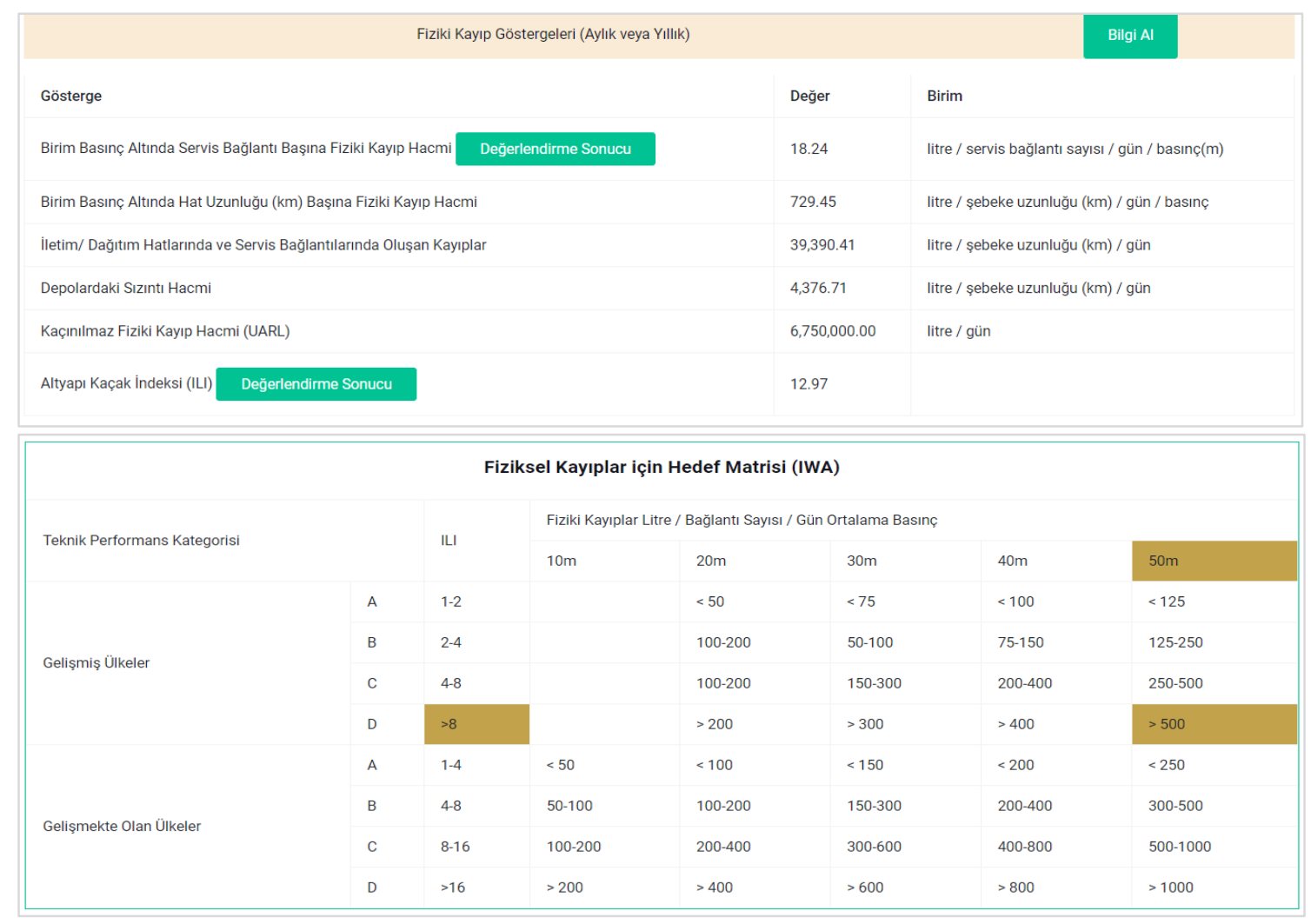

Şekil 5: Performans analizi hesaplama modülünde Fiziki kayıp göstergeleri

Bu göstergeler sızıntı miktarının şebeke uzunluğuna ve basınca göre değişimini vermektedir. Bir sistemde sızıntı önleme yöntemlerinin uygulanması veya basınç kontrolünün sağlanması ile sızıntıdaki değişiminin analiz edilmesi ve izlenmesi mümkün olmaktadır. Şekil 5'te verilen sonuçlara göre, sistemde ILI göstergesi 12.97 hesaplanmış ve literatürde verilen tabloya göre sistem D sınıfında (en kötü sınıf) yer almıştır. Buna göre bu sistem için önleme stratejisinin geliştirilmesi ve sistem performansının iyileştirilmesinin zorunlu olduğu görülmektedir. Uygulanacak yöntemlerin ve hedeflerin tanımlanmasında göstergeler esas alınarak daha gerçekçi yaklaşımların tanımlanması mümkün olacaktır. 


\section{4. İdari Kayıp Göstergeleri Modülü}

Dağıtım sistemlerinde idari kayıp oranı her ne kadar fiziki kayıplara göre düşük olsa da, bu kayıplar İdareler için doğrudan gelir kaybına neden olduğu için bunların azaltılması ve kontrol altına alınması önem taşımaktadır. Burada dikkate alınan göstergeler, idari kayıpların alt bileşenlerinin servis bağlantısına ve faturalandırılmış yasal kullanımlara göre değişimini vermektedir (Şekil 6). Bu göstergeler özellikle İdarenin servis bağlantı başına doğrudan kaybettiği gelirin analizinde ve süreç içindeki değişimin izlenmesinde önemlidir. Ayrıca faturalandırılan ve satılan su üzerinden ücreti alınmayan suyun ortaya konulması ve buna göre azaltma yöntemlerini uygulanmasıyla elde edilecek kazanımların hesaplanması mümkün olmaktadır. Bu hesaplama aracının, bu önemli göstergelerin sistematik ve doğru bir şekilde hesaplanması açısından İdareler için önemli katkılar sunacağı düşünülmektedir.

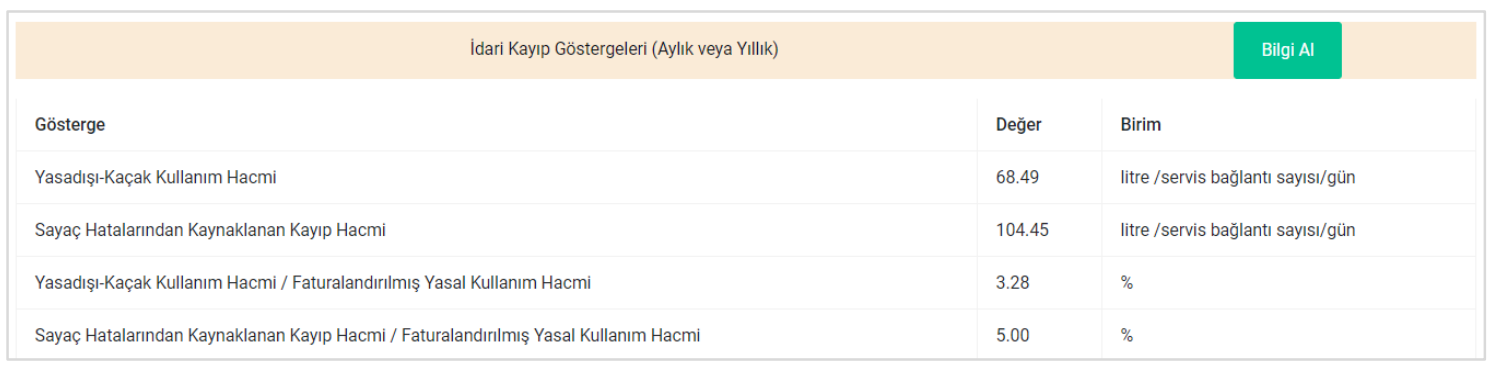

Şekil 6: Performans analizi hesaplama modülünde Idari kayıp göstergeleri

Bu göstergeler, İdarenin doğrudan gelir kaybını göstergen kayıpların analiz edilmesine imkan tanımaktadır. Sistemde kaçak kullanım ve sayaç hatalarından kaynaklanan kayıp hacimlerinin ve oranlarının hesaplanması ve izlenmesiyle, önleme yöntemlerden elde edilecek kazanımların hacimsel ve gelir olarak analizi mümkün olacaktır. Ayrıca bu bileşenlerin toplam gelir (faturalandırılmış yasal kullanım) içindeki oranı da hesaplanarak azaltılması gereken bileşenler belirlenmektedir.

\subsection{Ekonomik ve Maliyet Göstergeleri Modülü}

Su kayıplarının idarelere teknik etkisinin yanı sıra önemli ekonomik etkileri de söz konusudur. Ekonomik etki, su üretim aşamasından son kullanıcıya kadar geçen her aşamada, üretim, arıtma, terfi (enerji), arıza bakım onarım, işletme, sızıntılardan dolayı satılamayan suyun maliyeti şeklinde ortaya çıkmaktadır. Her bir bileşenin detaylı bir şekilde analiz edilmesi, gelir ve giderlerin kıyaslanması, su satış bedellerinin belirlenmesi için üretim ve işletme maliyetlerinin bilinmesi oldukça önemlidir. Ayrıca, su yönetiminde temel prensip sisteme verilen sudan maksimum fayda elde etmek olduğu için, okuma verimliliğinin \% 95 seviyelerinde tutulması, benzer şekilde tahsilat tahakkuk oranının da en \% 90-95 aralığında olması gerekir. Ancak bu kadar detaylı analizlerin sistematik ve doğru bir şekilde yapılması için uygun araçların kullanılması önemlidir. Bu nedenle bu çalışmada geliştirilen GGS performans analizi hesaplama aracında kentsel su yönetiminde önemli ekonomik göstergeler yer almakta ve analiz gerçekleştirilmektedir (Şekil 7). Böylece İdarelerde karar vericiler ve teknik personeller için sistem işletme verimliliğinin izlenmesi ve düşük performansa sahip bileşenlerin belirlenmesi mümkün olmaktadır. Bu hesaplama aracında su kayıplarının ekonomik etkilerinin analiz edilmesi için her bir bileşen bazında maliyetlerin hesaplandığı göstergeleri için GGS maliyet analizi modülü eklenmiştir (Şekil 8). Bilindiği üzere idari kayıpların maliyet hesabında suyun birim $\mathrm{m}^{3}$ satış bedeli üzerinden analiz yapılırken, fiziki kayıpların hesabında ise su üretim maliyeti dikkate alınmaktadır. Bu nedenle geliştirilen bu hesaplama aracında her bir bileşenin maliyet hesabında literatürde önerilen standartlar kullanılmıştır. 


\begin{tabular}{|c|c|c|c|}
\hline \multicolumn{3}{|r|}{ Ekonomik Göstergeler (Yillik) } & \multirow[t]{2}{*}{ Bilgi Al } \\
\hline Su Kayıp Ekonomi & Değer & Açıklama & \\
\hline Suyun Birim m3 için Satış Bedeli & 4.00 & Suyun Birim m3 için Satış Bedeli & $\mathrm{TL} / \mathrm{m} 3$ \\
\hline Sisteme Verilen Suyun Üretim Maliyeti & 2.00 & Suyun Üretim Maliyeti / Üretilen su hacmi & TL (ylllik toplam)/m3 \\
\hline Işletme Maliyeti & 3.60 & İşletme Maliyeti / Üretilen Su Hacmi & TL (ylllik toplam)/m3 \\
\hline Toplam Maliyet (üretim + ișletme) & 5.60 & (Üretim + İșletme Maliyeti) / Sistem net giriș Hacmi & TL (ylllik toplam)/m3 \\
\hline Iş̧letme Geliri & 4.00 & Ișletme Geliri / Sistem net giriş hacmi & TL (yllik toplam) / m3 \\
\hline Sisteme Verilen Suyun Üretim Maliyeti & 3.28 & Suyun Üretim Maliyeti / Faturalandırılmış Yasal Kullanım Hacmi & $\mathrm{TL} / \mathrm{m} 3$ \\
\hline Işletme Maliyeti & 5.90 & İşletme Maliyeti / FaturalandırıImış Yasal Kullanım Hacmi & TL (ylllik toplam)/m3 \\
\hline Toplam Maliyet (üretim + işletme) & 9.18 & (Üretim + Isșletme Maliyeti) / Faturalandırılmış Yasal Kullanım Hacmi & $\mathrm{TL} / \mathrm{m} 3$ \\
\hline İletilen Suyun Birim Geliri & 6.56 & Işsletme Geliri / FaturalandırıImış Yasal Kullanım Hacmi & TL (ylllik toplam) / m3 \\
\hline İşletme Maliyeti & $18,000,000.00$ & Işletme Maliyeti / Şebeke Uzunluğu $(\mathrm{km})$ * 100 & TL (yllik toplam) / 100 (km) \\
\hline İsletme Maliyeti & $4,500,000.00$ & İșletme Maliyeti / Servis Bağlantı Sayısı * 1000 & TL (ylllik toplam) / 1000 Servis Bağlantı \\
\hline Fatura Okuma Verimliliği & 80.00 & (Fatura Döneminde Okunan Abone Sayısı) / Toplam Abone SayıII & $\%$ \\
\hline Tahsilat Tahakkuk Oranı & 81.97 & Toplam Tahsilat Hacmi / Toplam Tahakkuk Hacmi & $\%$ \\
\hline İşletme Verimliliği & 111. 11 & Işletme Geliri / Toplam Işletme Gideri & $\%$ \\
\hline
\end{tabular}

Şekil 7: Performans analizi hesaplama modülünde ekonomik göstergeler

Su kayıplarının ekonomik ve maliyet açısından değerlendirilmesinde önemli bileşen, idare için yine doğrudan gelir kaybına neden olan faturalandırılmamış yasal kullanım gösterilebilir. Bu bileşene ait göstergeler analiz edilerek İdareye maliyetinin izlenmesi ve azaltma yöntemleri uygulanması durumunda elde edilecek kazanımların belirlenmesi mümkün olmaktadır. Bu kapsamda ayrıca her bir bileşen için sistem işletme maliyeti ve GGS toplam maliyeti ayrı ayrı hesaplanmakta ve karar vericiler için hangi bileşenin iyileştirilmesi gerekliliği noktasında önemli veriler üretilmektedir. Sonuç olarak geliştirilen bu hesaplama aracı, su kayıplarının ekonomik etkilerinin ortaya konulmasında, sistem işletme verimliliğinin analiz edilmesinde ve sistem performansının izlenmesinde İdareler için önemli bilgiler sunmakta ve referans teşkil edecek altlıklar oluşturmaktadır.

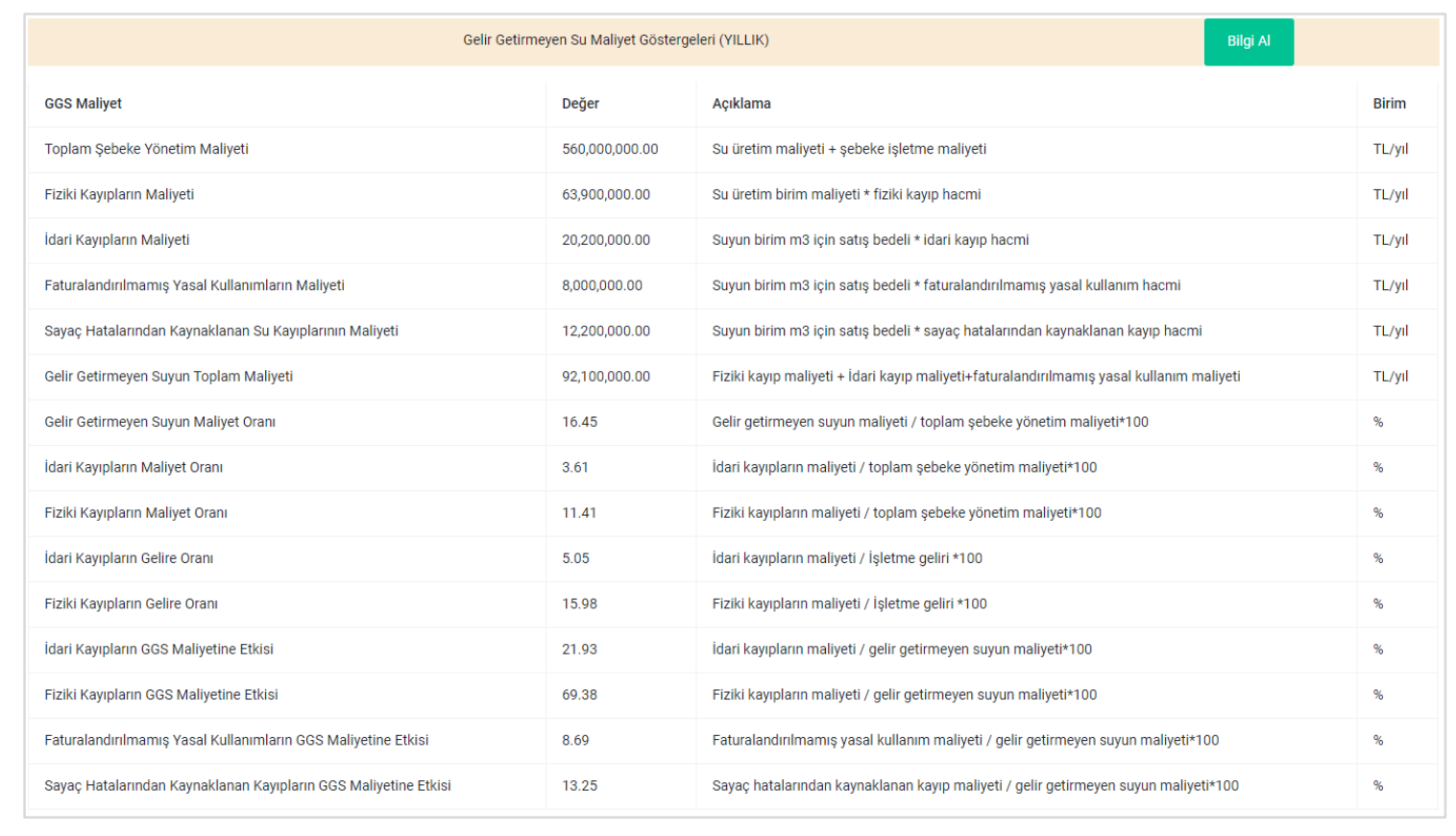

Şekil 8: Performans analizi hesaplama aracında GGS maliyet göstergeleri 


\subsection{Arıza Göstergeleri Modülü}

Dağıtım sistemlerinde medyana gelen arızalar rapor edilen ve rapor edilmeyen arızalar şeklinde tanımlanır. Bu arızaların önemli bir kısmı, malzeme kalitesi, işçilik ve çevresel etkilerinden dolayı servis bağlantılarında gözlenmektedir. Arıza sayılarının yüksek olması, sızıntı oranının artmasına, hizmet kalitesinin düşmesine, abone memnuniyetinin azalması, işletme bakım ve onarım maliyetlerinin artmasına ve terfili sistemlerde enerji maliyetlerinin artmasına neden olmaktadır. Yıllık arıza verileri şebeke borularının mevcut durumlarının belirlenmesinde temel ölçüt olarak kullanılmakta, İdarelerin sınırlı bütçeleri ile mevcut boruların durumunu değerlendirerek, bakım onarım, yenileme veya değiştirme faaliyetlerini değerlendirmesi ve öncelik belirlemesi gerekmektedir (Loganathan vd. 2002; Wang vd. 2009). Literatürde Lambert (1999) tarafından UARL denklemi geliştirilirken bir dağıtım sisteminde teknik olarak gözlenebilecek en düşük arıza sayıları, şebeke arızaları için 13/100 km şebeke uzunluğu/yıl, servis bağlantıları için 3/1000 servis bağlantı/yıl şeklinde tanımlanmıştır. Bir İdarede iyi çalışan bir arıza yönetim sistemi ile arıza verilerinin tutulması ve analiz edilmesi mümkün olmaktadır. Sistemin arıza oranları yönünden performansının analiz edilmesi için GGS performans analizi hesaplama aracına arıza oranı modülü eklenmiştir (Şekil 9). Bu modülde şebeke hattı ve servis bağlantılarında ayrı ayrı olmak üzere rapor edilen ve edilmeyen arıza oranları hesaplanmaktadır. Ayrıca şebeke ve servis bağlantılarında toplam arıza sayıları literatürde önerilen sınır değerlerle kıyaslanmakta ve arıza sıklık indeksi (1'e yakın olması sistemin çok iyi durumda olduğunu temsil eder) hesaplanmaktadır (Şekil 9). Bu şekilde detaylı yapılacak analiz ve hesaplamalar, sistemin işletme koşullarının iyileştirilmesi, işletme maliyetlerinin düşürülmesi ve arıza oranını azaltmak için en uygun stratejinin geliştirilmesi için önemli katkı sunacaktır.

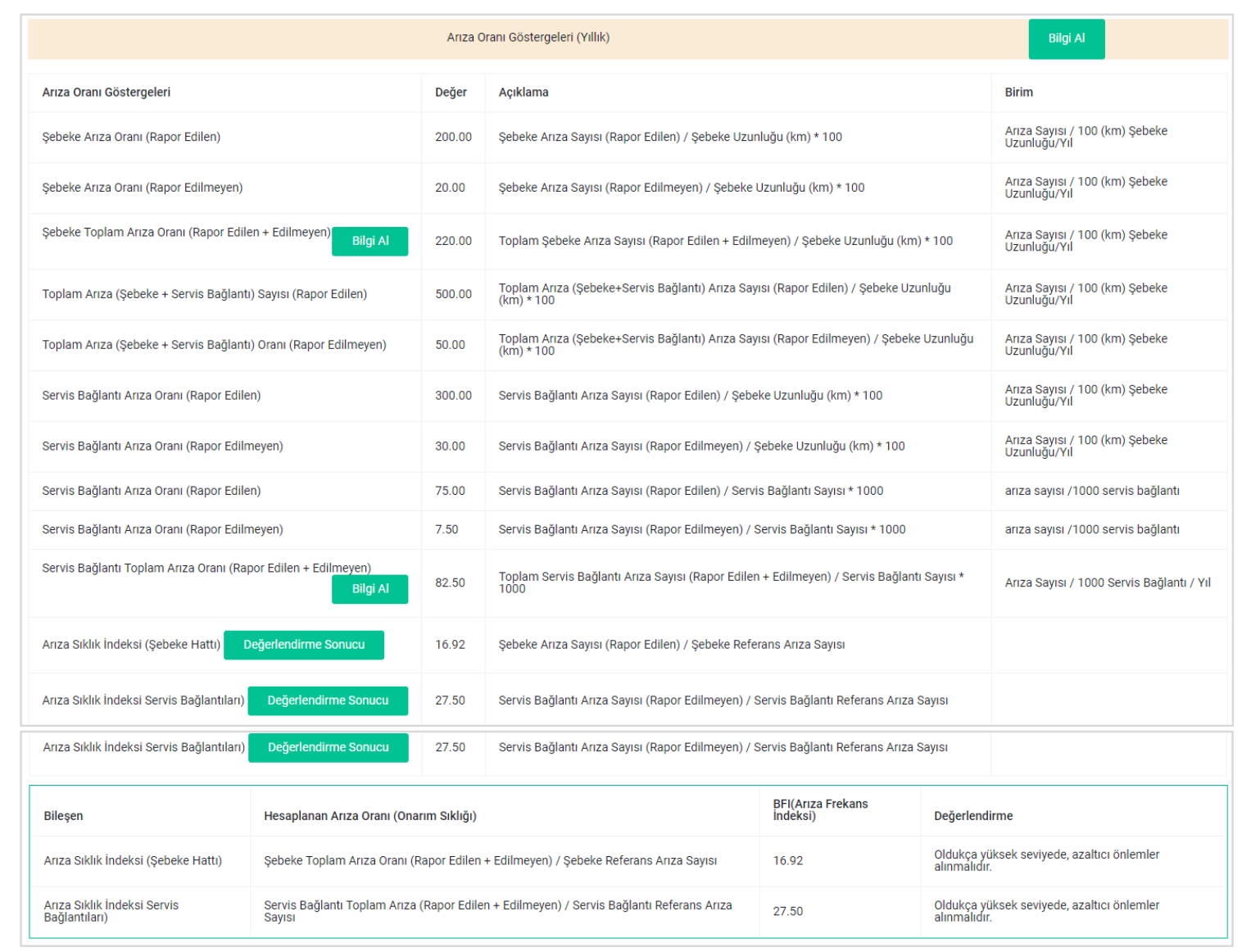

Şekil 9: Performans analizi hesaplama aracında arıza göstergeleri

$\mathrm{Bu}$ göstergeler özellikle bileşen analizi ile sızıntı hacminin belirlenmesinde, sistemin yıllık işletme, bakım ve onarım maliyetlerinin bölgesel olarak ve sistem geneli için hesaplanmasında kullanılmaktadır. Sistemde uygulanacak aktif kaçak kontrolü ve diğer yöntemlerin arıza oranlarındaki değişimlerin analiz edilmesi, bunların sistem işletme maliyetlerine etkisinin değerlendirilmesi mümkün olmaktadır. Ayrıca mevcut arıza sayılarına göre şebeke ve servis bağlantılarındaki arıza sıklık indisinin (1'e yakın olması istenen bir durum) analizi gerçekleştirilmektedir. Örnek bölge için yapılan hesaplamada, şebekedeki toplam arıza sayısının 220 arıza $/ 100 \mathrm{~km} / \mathrm{y} 1 \mathrm{l}$ olduğu ve bu değerin literatürde önerilen 13 arıza $/ 100 \mathrm{~km} /$ yıl değerinden oldukça yüksek seviyede olduğu görülmektedir. Benzer şekilde servis bağlantılarında arıza oranının $82.50 \mathrm{arıza} / 1000$ bağlantı/yıl olduğu ve sınır değerden (3 arıza/1000bağlant1/yıl) oldukça yüksek olduğu tespit edilmiştir. Şebeke ve servis bağlantılarında arıza sıklık indislerinin sırasıyla 16.92 ve 27.50 çıtığı görülmektedir. 
Bu hesaplamalar sistemde arıza oranlarının sınır değerlerden oldukça yüksek olduğu, bu oranın düşürülmesi için etkili faktörlerin detaylı bir şekilde analiz edilmesi gerektiğini göstermektedir. Bu yöntemlerin uygulanmasında sonra bu göstergeler tekrar hesaplanarak performans değişimleri analiz edilerek elde edilen kazanımların belirlenmesi mümkün olmaktadır.

\section{7. Şebeke Rehabilitasyon Göstergeleri Modülü}

Şebeke rehabilitasyonu bir sistemde su yönetiminde en maliyetli araç olarak karşımıza çıkmaktadır. Şebeke yenileme yaklaşımında, boru malzeme-işçilik-inşaat maliyetlerinin oldukça yüksek seviyelerde olması nedeniyle tercih edilmeden önce detaylı fayda maliyet analizinin yapılması ve alternatif çözümlerin de değerlendirilmesi gerekmektedir. Bu nedenle, mevcut şebekenin yapısal koşulları, hidrolik kapasitesi, zamana bağlı bozulma durumu göz önüne alınarak rehabilitasyon stratejinin belirlenmesi öncelik olmalıdır (Park ve Loganathan 2002; Kim vd. 2005; Tricarico vd. 2006; Francisque vd. 2017). Bu modülde, dağıtım sisteminde yıllık olarak rehabilitasyon yapılan boru oranı, servis bağlantı oranı ve değiştirilen vana oranı gibi göstergeler hesaplanmaktadır (Şekil 10). Özellikle rehabilitasyon oranı ile arıza oranlarının kıyaslanarak analiz edilmesine imkan tanımaktadır. Bu göstergelerin yıllara göre değişiminin izlenmesi, varlık yönetimi için referans teşkil edecek verilerin üretilmesi ve yapılacak yatırımların analiz edilmesi mümkün olmaktadır.

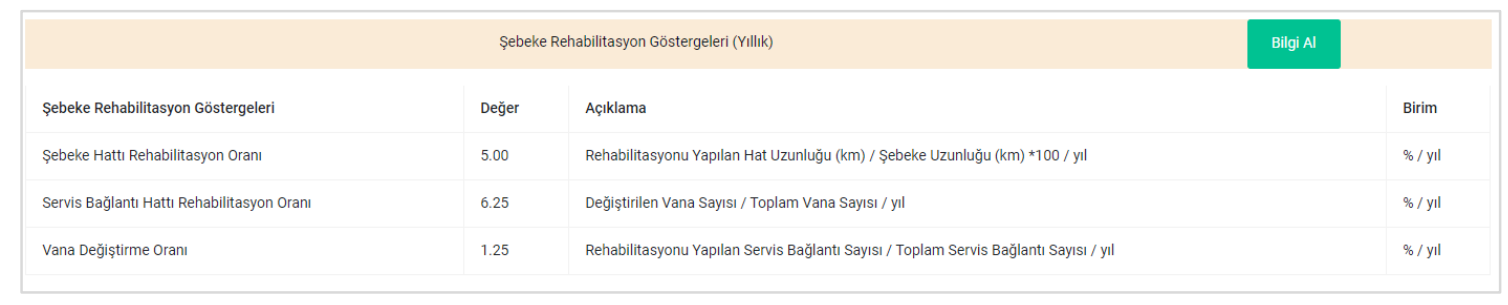

Şekil 10: Performans analizi hesaplama aracında şebeke rehabilitasyon göstergeleri

$\mathrm{Bu}$ göstergeler özellikle, sistemdeki bakım faaliyetlerinin ve yenileme çalışmalarının izlenmesi noktasında referans bilgi üretmektedir. Şebeke hattı ve servis bağlantılarındaki şebeke yenileme oranlarının hesaplanması yıllık yatırım bedellerinin hesaplanmasında kullanılmaktadır. Diğer taraftan vanaların bakım ve onarım performansının hesaplanmasında vana değiştirme oranları dikkate alınmaktadır. Bu göstergeler aynı zamanda sistemdeki ekonomik değerlendirilmesin yapılmasına da imkân tanımaktadır.

\subsection{Su Kaynağı ve Tüketim Göstergeleri Modülü}

Su kayıplarının teknik ve ekonomik etkilerinin yanı sıra çevresel ve ekolojik etkileri de önemli seviyelere ulaşabilmektedir. Özellikle sızıntı oranının fazla olduğu sistemlerde talebin karşılanması için sisteme daha fazla su verilmekte, yeni kaynaklar bulunmakta ve bunun sonucunda ekolojik denge bozulmaktadır. Bu hesaplama aracında sisteme verilen suyun verimli kullanma seviyesini ifade eden su kaynağı verimliliği göstergesi hesaplanmaktadır. Bu oran izlenerek yıllara göre veya aktif kaçak kontrolü stratejisine göre verimlilikte değişimin analiz edilmesi mümkün olmaktadır. Ayrıca kişi başı yıllık su üretim oranı ve tüketim oranları hesaplanmakta ve kıyaslanmaktadır. Bu göstergeler özellikle sisteme verilen suyun abonelere iletilmeyen (sızıntılar) kısmının belirlenmesinde oldukça önemlidir. Diğer taraftan, servis bağlantı başına su üretim ve tüketim verileri kıyaslanarak kaynağın verimli kullanılıp kullanılmadığı test edilmektedir. Sonuç olarak hesaplama aracı kapsamında geliştirilen bu modül, özellikle su kaynağının verimlilik analizinin yapılmasında, kişi ve servis bağlantı sayısına göre üretim ve tüketim verileri kıyaslanarak sızıntı miktarı ve faturalandırılan su miktarlarının analiz edilmesi mümkün olmakta ve karar vericiler için önemli katkılar sunmaktadır.

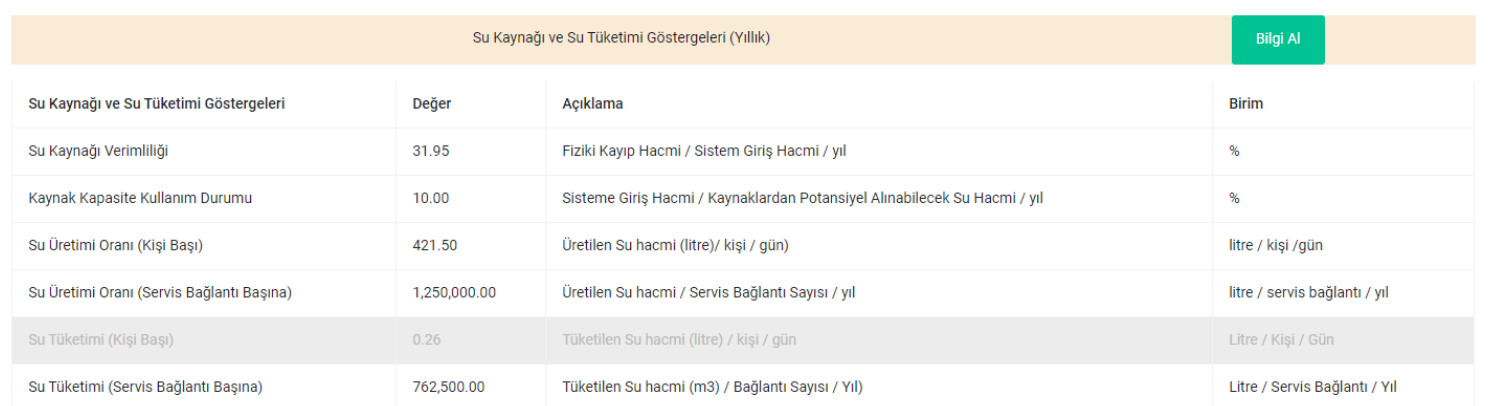

Şekil 11: Performans analizi hesaplama aracında su kaynağı ve tüketim göstergeleri 
Sonuç olarak, geliştirilen bu hesaplama aracı, bir Su İdaresinde su kayıplarının ve bileşenlerinin, sistem fiziksel özelliklerine (servis bağlantı sayısı ve hat uzunluğu), giriş hacmine (giriş hacminin yüzdesi), işletme verilerine (arıza oranları, şebeke rehabilitasyon), ekonomik verilere (su kayıplarının ekonomik ve maliyet değerleri) göre analiz edilmesi, performans değişiminin izlenmesi ve süreç performansının analiz edilmesi mümkün olmaktadır. Ülkemiz koşullarında bu kadar detaylı analizin doğru ve hassas bir şekilde gerçekleştirilmesine imkan tanıyan hesaplama aracının olmadığı göz önüne alındığında, bu çalışma kapsamında geliştirilen ve uygulanan hesaplama aracının İdarelerde karar vericiler ve teknik personel için önemli katkı sağlayacağı düşünülmektedir. İdarelerde bu hesaplama aracı kullanılarak göstergelerin hesaplanması, su, enerji, personel ve ekonomik verimliliğin analiz edilmesi ve iyileştirilmesi açısından referans teşkil edecek veriler üreteceği düşünülmektedir.

\section{Sonuçlar}

Bu çalışmada su kayıp yönetimi kapsamında İdarelerin performansının analiz edilmesi ve değerlendirilmesi amacıyla en uygun göstergeler belirlenmiş ve örnek veri seti için analiz yapılmıştır. Ayrıca belirlenen bu göstergelerin doğru, düzenli, sistematik ve hassas bir şekilde hesaplanması ve performansın izlenmesi için tabanlı "GGS temel performans analizi hesaplama aracı" geliştirilmiştir. Geliştirilen bu hesaplama aracı su kayıp yönetimi performansını toplam 10 başlık altında analiz etmektedir. Bu modüller temel olarak, hacimsel ve yüzdesel olarak, şebeke uzunluğuna ve birim servis bağlantı sayısına göre, idari ve fiziki kayıp, ekonomik ve finansal, arıza ve rehabilitasyon ana başlıklarında İdarenin performansını değerlendirmektedir. Her bir başlık ayrı bir modül olarak tasarlanmış ve hesaplanan her bir gösterge değerinin uluslar arası literatürde önerilen sınır değerlerle karşılaştırma imkanı sunulmuştur. Böylece sistemin bileşen bazında performansının değerlendirilmesi, süreç içinde değişimin izlenmesi ve öncellikli olarak iyileştirilmesi gereken bileşenin belirlenmesi mümkün olmaktadır. Bu hesaplama aracı, Su ve Kanalizasyon İdarelerinde ve İl Belediyelerinde su kayıp yönetimi faaliyetlerinin yürütülmesinde uygulanan yöntemlerin performansın hesaplanmasında, belirli bir zaman aralığında performans değişiminin izlenmesinde uygulanma potansiyeli bulunmaktadır. Ayrıca, verisi ölçülebilir, kıyaslanabilir ve uygulanabilir performans göstergelerin kullanılmasına ve bütünleşik bir şekilde hesaplanmasına imkan tanımaktadır. Bundan sonraki süreçte yapılacak akademik veya uygulama çalışmaları için referans teşkil edeceği düşünülmektedir. Geliştirilen bu hesaplama aracının, İdarelerin su kayıp yönetimi ve bileşenleri açısından performansının analiz edilmesi, izlenmesi, bu kadar detaylı ve önemli göstergelerin sistematik ve doğru bir şekilde hesaplanması ve aktif kaçak kontrolü faaliyetleri için süreç performansının değerlendirilmesinde önemli katkılar sağlayacağı düşünülmektedir.

\section{Teşekkür}

Bu çalışma, İnönü Üniversitesi Bilimsel Araştırma Projeleri Koordinasyon Birimi (İÜ-BAP FOA-2018-626) tarafından desteklenmiştir.

\section{Kaynaklar}

Alegre H., Baptista J.M., Cabrera Jr E., Cubillo F., Duarte P., Hirner W., Merkel W., Parena R., (2006), Performance Indicators for Water Supply Services - Second Edition, IWA Publishing, London, UK, 312ss.

Alegre H, Baptista J.M., Cabrera Jr E., Cubillo F., Duarte P., Hirner W., Merkel W., Parena R., (2016), Performance Indicators for Water Supply Services: Third Edition, IWA Publishing, London, UK, 404ss.

Chimene C., (2013), Strategies and Methods for Apparent Water Loss Management in Developing Countries A Case Study of Mozambique, MSc Thesis, UNESCO-IHE Institute for Water Education, Delft, the Netherlands.

Creaco E., Walski T., (2018), Economic analysis of pressure control for leakage and pipe burst reduction, Journal of Water Resources Planning and Management, 143(12):04017074-1.

Güngör-Demirci G., Lee J., Keck J., (2018), Assessing the performance of a California water utility using two-stage data envelopment analysis, Journal of Water Resources Planning and Mangement, 144(4):05018004-1.

Farley M., Trow S., (2003), Losses in water distribution networks : a practitioner s guide to assessment, monitoring and control, IWA Publishing, London, UK, ss.273.

Farley M., Wyeth G., Ghazali Z.B.M., Istandar A., Singh S., (2008), The Manager's Non-Revenue Water Handbook: A Guid to Underst Water Losses, Ranhill Util Bernhad USAID, Malaysia, 110ss.

Francisque A., (2017), Water mains renewal planning framework for small to medium sized water utilities: a life cycle cost analysis approach, Urban Water Journal, 14(5), 493-501.

Ganjidoost A., Knight M.A., Unger A.J.A., Haas C.T., (2018), Benchmark Performance Indicators for Utility Water and Wastewater Pipelines Infrastructure, Journal of Water Resources Planning and Mangement, 144(3):04018003-1.

Haider H., (2015), Performance management framework for small to medium sized water utilities: conceptualization to development and implementation, $\mathrm{PhD}$ Thesis, The University of British Columbia, Canada.

Hamilton S., Mckenzie R., Seago C., (2006), A Review of Performance Indicators for Real Losses from Water Supply Systems, Voda i Sanitarna Tehnika, 36(6), 15-24.

Kanakoudis V., Tsitsifli S., Samaras P., Zouboulis A., (2014), Water pipe networks performance evaluation, Department of Civil Engineering, University of The Twentieth Anniversary Volume, ss.211-226.

Kim E.S., Baek C.W., Kim J.H., (2005), Estimate of pipe deterioration and optimal scheduling of rehabilitation, Water Science and Technology: Water Supply, 5(2), 39-46. 
Lambert A.O., Brown T.G., Takizawa M., Weimer D., (1999), A review of performance indicators for real losses from water supply systems. J Water Supply Res Technol - AQUA, 48, 227-237.

Lambert A.O., (2002), International report: Water losses management and techniques. Water Science and Technology: Water Supply, 2(4), 1-20.

Lambert A.O., Lalonde A., (2005), Using practical predictions of Economic Intervention Frequency to calculate Short-run Economic Leakage Level, with or without Pressure Management, Procedings of IWA Specialised Leakage 2005 Conference, Halifax, Nova Scotia, Canada, ss.310-321.

Liemberger R., Brothers K., Lambert A., Mckenzie R.S., Rizzo A., Waldron T., (2007), Water loss performance indicators, Proceedings of IWA Specialised Conference Water Loss 23th-26th September, 2007. Bucharest-Cyprus, London, IWA Publishing, B2(1), ss.148-160.

Loganathan G.V., Park S., Sherali H.D., (2002), Threshold break rate for pipeline replacement in water distribution systems, Journal of Water Resources Planning and Management, 128(4), 271-279.

Mutikanga H., Sharma S., Vairavamoorthy K., Cabrera Jr E., (2010), Using performance indicators as a water loss management tool in developing countries, J Water Supply Res Technol - AQUA, 59(8): 471-481.

Park S.W., Loganathan G.V., (2002), Methodology for economically optimal replacement of pipes in water distribution systems: 2. Applications, KSCE Journal of Civil Engineering, 6(4), 545-550.

Pearson D., Trow S.W., (2005), Calculating the Economic Levels of Leakage, Procedings of IWA Specialised Leakage 2005 Conference, Halifax, Nova Scotia, Canada, ss.294-309.

Sharma S., (2008), Performance Indicators of Water Losses in Distribution Systems. UNESCO-IHE Inst Water Educ, available at: www.switchurbanwater.eu/outputs/pdfs/GEN_PRS_PI_of_Water_Losses_AC_Apr08.pdf, [Erişim 28 Haziran 2016].

Shinde V.R., Hirayama N., Mugita A., Itoh S., (2013), Revising the existing Performance Indicator system for small water supply utilities in Japan, Urban Water Journal, 10(6), 377-393.

Tricarico C., (2006), Economic level of reliability for the rehabilitation of hydraulic networks, Civil Engineering and Environmental Systems, 23(3), 191-207.

van den Berg C., Danilenko A. (2010), The IBNET Water Supply and Sanitation Performance Blue Book, World Bank, https://openknowledge.worldbank.org/handle/10986/2545, [Erişim 15 Mart 2020].

Wang Y., Zayed T., Moselhi O., (2009), Prediction Models for Annual Break Rates of Water Mains, Journal of Performance of Constructed Facilities, 23(1), 47-54. 